\title{
Inhibition of HIV-1 Replication by Cyclopentenone Prostaglandins in Acutely Infected Human Cells

\author{
Evidence for a Transcriptional Block
}

\author{
Carmela Rozera, ${ }^{*}$ Alessandra Carattoli, ${ }^{*}$ Alessandra De Marco, ${ }^{\circ}$ Carla Amici, $\$$ Colomba Giorgi, ${ }^{*}$ and M. Gabriella Santoro $\neq \|$ \\ * Laboratory of Virology, ISS, 00161 Rome, Italy; ${ }^{\ddagger}$ Department of Experimental Medicine, University of L'Aquila, 67100 L'Aquila, Italy;

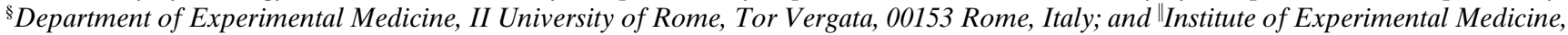 \\ CNR, 00137 Rome, Italy
}

\begin{abstract}
Cyclopentenone prostaglandins (PGs) inhibit virus replication in several DNA and RNA virus models, in vitro and in vivo. In the present report we demonstrate that the cyclopentenone prostaglandins $\mathrm{PGA}_{1}$ and $\mathrm{PGJ}_{2}$ at nontoxic concentrations can dramatically suppress HIV-1 replication during acute infection in CEM-SS cells. PGs did not affect HIV-1 adsorption, penetration, reverse transcriptase activity nor viral DNA accumulation in HIV-1 infected cells. A dramatic reduction in HIV-1 mRNA levels was detected up to 48-72 h after infection (p.i.) in PG-treated cells, and HIV-1 protein synthesis was greatly reduced by a single PGtreatment up to $96 \mathrm{~h}$ p.i. Repeated $\mathrm{PGA}_{1}$-treatments were effective in protecting CEM-SS cells by the cytopathic effect of the virus, and in dramatically reducing HIV-1 RNA levels up to $7 \mathrm{~d}$ after infection. The antiviral effect was not mediated by alterations in the expression of $\alpha-, \beta-$, or $\gamma$-interferon, TNF $\alpha$, TNF $\beta$, IL6, and IL10 in HIV-infected CEMSS cells. The fact that prostaglandins are used clinically in the treatment of several diseases, suggests a potential use of cyclopentenone PGs in the treatment of HIV-infection. $(J$. Clin. Invest. 1996. 97:1795-1803.) Key words: antiviral • AZT $\bullet$ heat shock proteins $\bullet \mathrm{HIV}-1 \cdot$ prostaglandins
\end{abstract}

\section{Introduction}

Since the discovery of the human immunodeficiency virus (HIV) as the causative agent of acquired immune deficiency syndrome (AIDS), a number of compounds with antiretroviral activity have been identified (1). Although there has been considerable progress both in the understanding of the complex and multifactorial regulation of HIV replicative strategy, and in the management of chronic HIV infection, at present no effective treatment exists. Antiretroviral treatment with zidovudine or 2', 3'-dideoxyinosine and 2', 3'-dideoxycytidine, which inhibit reverse transcriptase activity (1), has limited efficacy in patients treated for prolonged periods (2), and the search for new antiviral drugs effective on different targets of HIV repli-

Address correspondence to M. Gabriella Santoro, Institute of Experimental Medicine, CNR, Via.le K. Marx, 15, 00137 Rome, Italy. Phone: 6-86090325; FAX: 6-86090332.

Received for publication 14 August 1995 and accepted in revised form 16 January 1996.

J. Clin. Invest.

(C) The American Society for Clinical Investigation, Inc.

0021-9738/96/04/1795/9 \$2.00

Volume 97, Number 8, April 1996, 1795-1803 cation cycle is needed to improve the therapeutic efficacy in $\mathrm{HIV}$-infection and impair the progression of the disease.

The ability of prostaglandins (PGs) of the A type (PGAs) to inhibit virus replication and prevent the establishment of persistent infections was first reported in 1980 (3). It is now well established that PGs containing an $\alpha, \beta$-unsaturated carbonyl group in the cyclopentane ring structure (cyclopentenone PGs, i.e. PGAs and PGJs) possess a potent antiviral activity against a wide variety of DNA and RNA viruses, including herpesviruses $(4,5)$, poxviruses $(6)$, paramyxoviruses $(3,7)$, orthomyxoviruses (8), picornaviruses (9), togaviruses (10) and rhabdoviruses $(11,12)$. The antiviral activity of a long acting synthetic analogue of $\mathrm{PGA}_{2}, 16,16$-dimethyl-PGA methyl ester (di-M-PGA $A_{2}$ has been reported in vivo, in a mouse model infected with influenza A virus (8).

Prostaglandins of the A type have also been shown to inhibit the replication of retroviruses. $\mathrm{PGA}_{1}$ was able to prevent the clonal selection of human $\mathrm{T}$ cell leukemia virus-type 1 (HTLV-1)-infected cord blood-derived mononuclear cells (13). Ankel et al. (14) reported that $\mathrm{PGA}_{1}$ and $\mathrm{PGA}_{2}$, but not $\mathrm{PGB}_{1}, \mathrm{PGE}_{1}$ and $\mathrm{PGE}_{2}$, dramatically inhibited the replication of human immunodeficiency virus-type 1 (HIV-1) in C8166 cells. More recently, Hughes-Fulford et al. (4) have shown the antiviral efficacy of the $\mathrm{PGA}_{1}$ analogue, dimethyl $\mathrm{PGA}_{1}$, against HIV-1 in acutely infected T-lymphoma VB cells and in chronically infected macrophages. Higher concentrations of the drug were necessary to reduce p24 antigen levels in chronically infected cells as compared with acutely infected cells (4). Both authors suggested a possible use of PGAs or their synthetic analogs as antiviral agents in humans, specifically in the treatment of AIDS.

The mechanism of the antiviral activity of cyclopentenone prostaglandins has been mainly studied in negative-strand RNA virus models. In paramyxoviruses and rhabdoviruses the antiviral activity is mediated by alterations in the synthesis, maturation and intracellular translocation of specific virus proteins, and has been associated with the induction of the synthesis of heat shock proteins (HSP) ${ }^{1}$ from the host cell (reviewed in reference 15). However, the mechanism of $\mathrm{PGA}_{1}$ antiviral activity in cells infected with retroviruses is unknown.

In the present report we have studied the effect of the cyclopentenone prostaglandins $\mathrm{PGA}_{1}$ and $\mathrm{PGJ}_{2}$ on $\mathrm{HIV}-1$ replication in CEM-SS cells during acute infection. Both prostaglandins were found to be extremely effective in inhibiting HIV-1 replication in these cells. The antiviral activity was not due to alterations in the adsorption and penetration of the virus into the host cell, nor to an effect on an early event in HIV-1

1. Abbreviation used in this paper: HSP, heat shock protein. 
replication cycle. A dramatic block of HIV-1 RNA expression was instead detected in cells treated with cyclopentenone PGs.

\section{Methods}

Cell culture and virus. CEM-SS cells, derived from the human T lymphoid cell line CEM that expresses high levels of T4 antigen (16) were maintained at the density of $5 \times 10^{5} \mathrm{cells} / \mathrm{ml}$ in suspension medium RPMI 1640 (GIBCO BRL, Gaithersburg, MD) containing $2 \mathrm{mM}$ L-glutamine, $10 \%$ heat-inactivated fetal calf serum (FCS, Hyclone Europe Ltd., UK) and antibiotics at $37^{\circ} \mathrm{C}$ in a $5 \% \mathrm{CO}_{2}$ atmosphere. $\mathrm{H} 9$ cells, a human $\mathrm{CD}^{+}$lymphocyte line (17), chronically infected with HIV-1, and the $\mathrm{CD}^{+}$human $\mathrm{T}$ cell line C8166, were grown in RPMI 1640 medium as described above. $\mathrm{PGA}_{1}$ and $\mathrm{PGJ}_{2}$ (Cayman Chemical Co., Ann Arbor, MI) were stored as $100 \%$ ethanolic stock solution $(10 \mathrm{mg} / \mathrm{ml})$ at $-20^{\circ} \mathrm{C}$, and were diluted to the appropriate concentration in culture medium immediately before use. Azidothymidine (AZT; Sigma Chemical Co., St. Louis, MO) was dissolved in PBS and used at the final concentrations of $5 \mu \mathrm{M}$.

HIV-1, isolate HTLV-III ${ }_{B}$, (17) was used in this study. An HIV-1 stock with a high infectivity was prepared by coculturing CEM-SS cells pretreated with Polybrene $(8 \mu \mathrm{g} / \mathrm{ml}$; Sigma Chemical Co.) for $12 \mathrm{~h}$, with chronically infected $\mathrm{H} 9$ cells (3:1 ratio). At the time of appearance of syncytia, the culture medium was changed and virus-containing supernatant was harvested after 24 or $48 \mathrm{~h}$. After clarification at $2000 \mathrm{rpm}$ for $20 \mathrm{~min}$ and filtration, the titer of the viral stock was evaluated using C8166 cells, according to the standard dilution procedure (18).

Virus infection and titration. For HIV-1 infection, CEM-SS cells were exposed for one hour at $37^{\circ} \mathrm{C}$ to HIV-1 at an infectious multiplicity of $0.1-10 \mathrm{TCID}_{50}$ per cell $\left(10^{6}\right.$ cells $\left./ \mathrm{ml}\right)$. After the $1 \mathrm{~h}$ adsorption period, virus was removed, and cells were washed in culture medium and resuspended at the concentration of $5 \times 10^{5}$ cells $/ \mathrm{ml}$ in fresh RPMI 1640 supplemented with $10 \%$ FCS, glutamine and antibiotics. $\mathrm{PGA}_{1}, \mathrm{PGJ}_{2}$ or the corresponding amount of control diluent were added immediately after washing, unless differently specified. Uninfected CEM-SS cells were treated identically. Appearance of syncytia were determined daily by microscopical examination. The absolute number of cells in uninfected and HIV-1 infected CEM-SS cultures was determined by counting in a hemocytometer; viability was determined by vital dye exclusion technique.

For virus titration, one $\mathrm{ml}$ aliquots of CEM-SS cells were collected at different times p.i., pelleted and stored at $-70^{\circ} \mathrm{C}$ for p24 gag antigen determination by ELISA (Dupont Denemours, Bruxelles, Belgium). Supernatants were also collected, filtered and stored at $-70^{\circ} \mathrm{C}$ for determination of HIV-1 p24 antigen or infectious virus titers. Virus titers were determined by the standard dilution procedure, as described above. Each sample was tested in triplicate. Each experiment was repeated at least three times.

$D N A, R N A$ and protein synthesis. DNA, RNA and protein synthesis were determined in CEM-SS cells after treatment with $\mathrm{PGA}_{1}$ $(4 \mu \mathrm{g} / \mathrm{ml})$ or control diluent. Cells were labeled for a period of $24 \mathrm{~h}$ with $5 \mu \mathrm{Ci} / \mathrm{ml}$ per $1 \times 10^{6}$ cells of $\left[{ }^{3} \mathrm{H}\right]$ thymidine, $\left[{ }^{3} \mathrm{H}\right]$ uridine, or $\left[{ }^{35}\right.$ S $]$ methionine (Amersham International, Buckinghamshire, England) for DNA, RNA or protein synthesis respectively, and the radioactivity incorporated into acid-soluble and -insoluble material was determined. Briefly, cells were washed three times with PBS, and 5\% TCA $(0.4 \mathrm{ml})$ was added to each culture. After $1 \mathrm{~h}$ at $4^{\circ} \mathrm{C}$, the radioactivity of acid-soluble material was determined. Acid-insoluble radioactivity was measured after washing three times the TCA precipitates with ethanol, drying under an infrared lamp and dissolving the samples in $0.4 \mathrm{ml}$ of a solution containing $0.1 \mathrm{M} \mathrm{NaOH}, 0.5 \%$ SDS.

Northern blot analysis. At different times after HIV-1 infection, total cellular RNA was isolated by the guanidinium isothiocianate method, as described (19). Total RNAs $(5 \mu \mathrm{g})$ were analyzed after electrophoresis through $1 \%$ agarose gels containing $2.5 \%$ formaldehyde, transferred onto Hybond-N nylon membranes (Amersham), and hybridized at $42^{\circ} \mathrm{C}$ with a full length HIV-1 DNA probe, pUCF12-HIV-1 (20), ${ }^{32} \mathrm{P}$-labeled by random-priming in $50 \%$ formamide, $6 \times$ SSC, $5 \times$ Denhardt's solution, $0.5 \%$ SDS, $100 \mu \mathrm{g} / \mathrm{ml}$ denatured fragmented salmon sperm DNA. Blots were then washed twice for $15 \mathrm{~min}$ at $42^{\circ} \mathrm{C}$ with $2 \times \mathrm{SSC}$ and once with $0.1 \times \mathrm{SSC}$, air dried and autoradiographed at $-70^{\circ} \mathrm{C}$. For loading control, after being stripped, filters were rehybridized at $42^{\circ} \mathrm{C}$ in $5 \times \mathrm{SSC}, 5 \times$ Denhardt's solution, $50 \mathrm{mM} \mathrm{Na} 2 \mathrm{HPO}_{4} / \mathrm{NaH}_{2} \mathrm{PO}_{4}$ (pH 6.8), $0.3 \%$ SDS, $50 \mu \mathrm{g} / \mathrm{ml}$ denatured fragmented salmon sperm DNA, with an antisense oligonucleotide specific for the glyceraldehyde phosphate dehydrogenase gene (GAPDH; 5'-GCTAAGCAGTTGGTGGTGCAGGA-3') 5' end-labeled by T4 Kinase with $\gamma$-AT ${ }^{32} \mathrm{P}$ (Amersham) $\left(5 \times 10^{6} \mathrm{cpm} /\right.$ $\mathrm{ml})$. Filters were washed under stringent conditions $(0.1 \times \mathrm{SSC}, 0.1 \%$ SDS) and autoradiographed at $-70^{\circ} \mathrm{C}$.

Southern blot analysis. Uninfected or HIV-1 infected CEM-SS cells $\left(1 \times 10^{7}\right)$ were lysed in $100 \mathrm{mM} \mathrm{NaCl}, 10 \mathrm{mM}$ Tris $\mathrm{HCl} \mathrm{pH} 8,25$ $\mathrm{mM}$ EDTA $\mathrm{pH} 8,0.5 \%$ SDS and $100 \mu \mathrm{g} / \mathrm{ml}$ proteinase $\mathrm{K}(18 \mathrm{~h}$ at $50^{\circ} \mathrm{C}$ ), and DNA was isolated as described previously (21). Isolated DNA $(70 \mu \mathrm{g})$ was digested for $3 \mathrm{~h}$ at $37^{\circ} \mathrm{C}$ with $\operatorname{EcoRI}(200 \mathrm{U})$ and BamHI (200 U) which recognize restriction sites within the HIV-1 genome at nucleotides 4647 and 5742 (EcoRI) and 8474 (BamHI) respectively. Digested DNA was then electrophoresed on a $1 \%$ agarose gel, transferred to Hybond-N nylon membranes (Amersham), and hybridized at $65^{\circ} \mathrm{C}$ with the pUCF12-HIV-1 plasmid $\left(5 \times 10^{6} \mathrm{cpm} /\right.$ $\mathrm{ml}$ ), labeled with $\left[\alpha^{-32} \mathrm{P}\right] \mathrm{dCTP}$ (Amersham) by random priming (Random Primed DNA labeling kit; Boehringer Mannheim GmbH, Mannheim, Germany), in $5 \times$ SSC, $5 \times$ Denhardt's solution, $0.5 \%$ SDS, $20 \mu \mathrm{g} / \mathrm{ml}$ denatured fragmented salmon sperm DNA. Blots were then processed for autoradiography, as described above. Two HIV-1 DNA fragments of $\sim 1.100$ and $2.700 \mathrm{bp}$ were identified with this procedure, as expected (22).

Immunoblot analysis. Uninfected and HIV-1 infected CEM-SS cells were washed twice with PBS and lysed in lysis buffer containing $50 \mathrm{mM}$ Tris (pH 7.2), $150 \mathrm{mM} \mathrm{NaCl}, 0.1 \%$ SDS, $2 \mathrm{mM}$ PMSF. An equal amount of protein for each sample $(100 \mu \mathrm{g})$ was separated on $10 \%$ SDS-PAGE gels under reducing conditions, and electroblotted to nitrocellulose filters, as described (7). After transfer, filters were incubated with goat serum containing anti-HIV-1 or anti-p24 gag protein antibodies (Biogenesis Ltd., Poole, England). Antigen-antibody complexes were then detected by horseradish peroxidase-linked anti-goat antibodies (Amersham). Molecular weights were calculated using Bio-Rad low $M_{\mathrm{r}}$ markers, as described (7).

Reverse transcriptase $(R T)$ activity assay. The magnesium-dependent RT activity was determined as previously described (23). Briefly, disrupted stock virus $(30 \mu \mathrm{l})$ was mixed with $70 \mu \mathrm{l}$ of RT reaction mixture containing poly(A), oligo (dT) $(5 \mu \mathrm{g} / \mathrm{ml}$; Pharmacia Biotech Inc., Piscataway, NJ) in $50 \mathrm{mM}$ Tris $(\mathrm{pH} 7.8), \mathrm{MgCl}_{2}(5 \mathrm{mM})$ and $\left[{ }^{3} \mathrm{H}\right]$ thymidine (Amersham), and incubated for $1 \mathrm{~h}$ at $37^{\circ} \mathrm{C}$. Samples were then spotted onto nitrocellulose filters, and washed 3 times with $5 \%$ TCA. The radioactivity on the filters was determined by counting in a scintillation counter.

Statistical analysis. Statistical analyses were performed using the Student's $t$ test for unpaired data. Data are expressed as the mean \pm SD; $P$ values of $<0.05$ were considered significant.

\section{Results}

Anti-HIV activity of $P G A_{1}$ in CEM-SS cells. CEM-SS cells were infected with HIV-1 (0.1 TCID 50 cell) and treated with different concentrations of $\mathrm{PGA}_{1}$ or control diluent soon after the $1 \mathrm{~h}$ adsorption period. In the absence of $\mathrm{PGA}_{1}, \mathrm{HIV}-1$ was highly cytopathic for CEM-SS, causing syncytia formation at $48 \mathrm{~h}$ p.i., and cell death $7 \mathrm{~d}$ after virus infection. $\mathrm{PGA}_{1}$ treatment substantially decreased the number and size of virus-induced syncytia and prolonged for several days (3-4 d) the survival of infected cells.

Virus release from untreated and $\mathrm{PGA}_{1}$-treated infected 
cells was assessed at different times p.i. by determining HIV-1 p24 antigen production and the titer of infectious virus in the supernatant of infected cells. As shown in Fig. $1 A, \mathrm{PGA}_{1}$ treatment caused a dose-dependent decrease in p24 antigen production $96 \mathrm{~h}$ p.i., and an inhibition of $\sim 90 \%$ was obtained at concentrations of $2-4 \mu \mathrm{g} / \mathrm{ml}$, while higher concentrations of $\mathrm{PGA}_{1}$ almost completely abolished p24 antigen production. The titer of infectious virus in the supernatant was also dramatically decreased in $\mathrm{PGA}_{1}$-treated cells, and an inhibition of more than 4000-fold was detected in samples treated with $4 \mu \mathrm{g} / \mathrm{ml} \mathrm{PGA}_{1}$ at $72 \mathrm{~h}$ p.i., at which time p24 antigen production was decreased by approximately $80 \%$ in the same samples (Fig. $1 A$, inset).
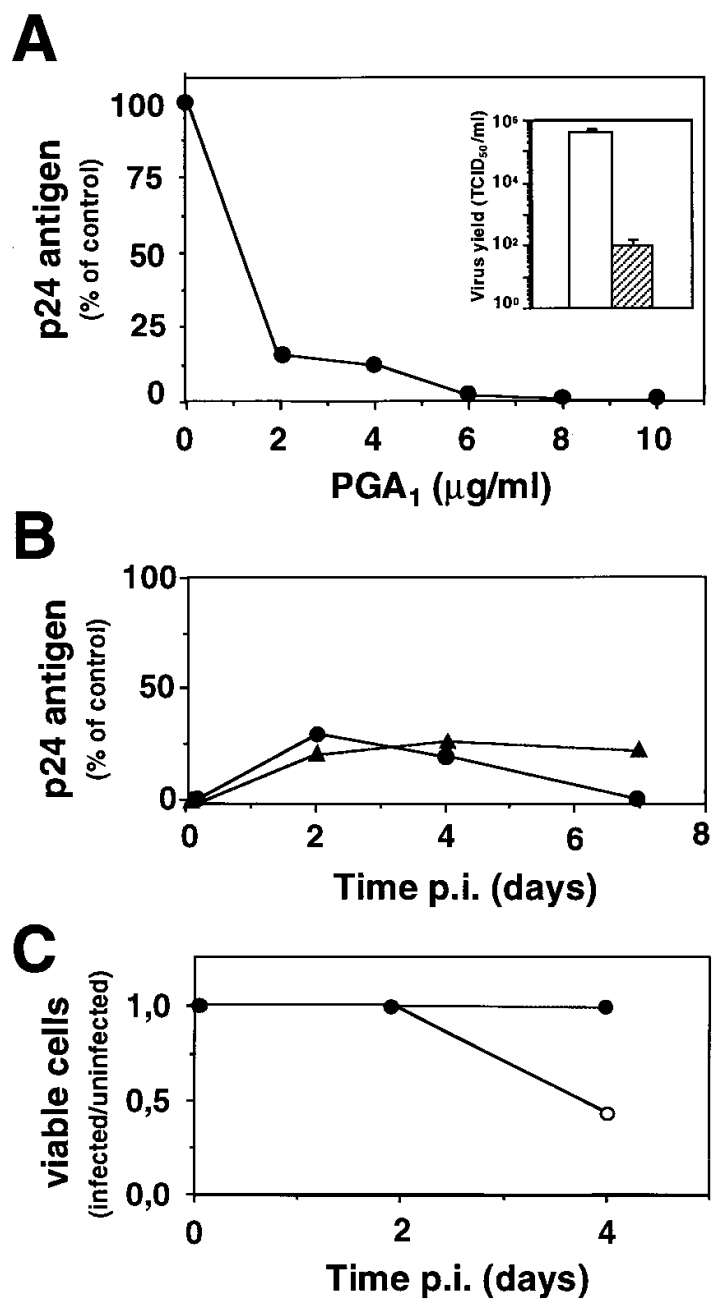

Figure 1. Inhibition of HIV-1 replication by $\mathrm{PGA}_{1}$ in CEM-SS cells. (A) CEM-SS cells infected with HIV-1 were treated with different concentrations of $\mathrm{PGA}_{1}$ or control diluent soon after the $1 \mathrm{~h}$ adsorption period. P24 antigen production was determined $96 \mathrm{~h}$ p.i. by ELISA. Results are expressed as percent of p24 antigen production in untreated control (control $=152.0 \pm 9.3 \mathrm{ng} / \mathrm{ml})$. Inhibition of infectious virus production by $\mathrm{PGA}_{1}(4 \mu \mathrm{g} / \mathrm{ml}$; hatched bar $)$ at $72 \mathrm{~h}$ p.i. is shown in $A$, inset. (B) Effect of $\mathrm{PGA}_{1}(4 \mu \mathrm{g} / \mathrm{ml})$ on extracellular $(\bullet)$ or intracellular $(\boldsymbol{\Lambda})$ p24 antigen production at different times after HIV-1 infection. (C) Effect of PGA 1 on HIV-1 cytopathic effect on day 2 and 4 p.i. Data represent the ratio between viable cells counts in infected cultures and viable cell counts in uninfected cultures for each time point. $(\bigcirc)$ control, $(\bullet) \mathrm{PGA}_{1}(4 \mu \mathrm{g} / \mathrm{ml})$. SD $<10 \%$ are not shown.
The concentration of $4 \mu \mathrm{g} / \mathrm{ml}$ was found to be the most active non toxic dose, not altering cell viability or RNA and DNA synthesis in uninfected CEM-SS cells (see below) and was used in all the following experiments. A single treatment with $\mathrm{PGA}_{1}(4 \mu \mathrm{g} / \mathrm{ml})$ started soon after the $1 \mathrm{~h}$ adsorption period, resulted in a sustained inhibition of virus production up to $7 \mathrm{~d}$ p.i. (Fig. $1 B$ ). The antiviral activity was accompanied by a protection of CEM-SS cells by the cytopathic effect of the virus, as shown by determining the number of viable cells in uninfected or HIV-1 infected cells treated with $\mathrm{PGA}_{1}$ or control diluent (Fig. $1 \mathrm{C}$ ). At $96 \mathrm{~h}$ p.i., the number of viable cells in HIV-1 infected cultures increased from less than $50 \%$ in untreated cells to $>90 \%$ in $\mathrm{PGA}_{1}$-treated cells.

Under the conditions described above, $\mathrm{PGA}_{1}$ at the concentration of $4 \mu \mathrm{g} / \mathrm{ml}$ was not toxic to uninfected CEM-SS cells as determined by microscopic examination and vital dye uptake (Fig. 2). As previously described in different cell lines (24), $\mathrm{PGA}_{1}$ caused a moderate inhibition of cell proliferation at $48 \mathrm{~h}$ after the beginning of treatment, after which time cell proliferation rate went back to the normal level, unless the treatment was repeated (data not shown). A 24 h PGA -treat- $^{-}$ ment also did not inhibit RNA or DNA synthesis in uninfected CEM-SS cells (Fig. 2).

To investigate the effect of $\mathrm{PGA}_{1}$-treatment after infection with different concentrations of HIV-1, CEM-SS cells were infected with HIV-1 at 0.01, 0.1, 0.5, and 1 TCID $_{50} /$ cell and, after
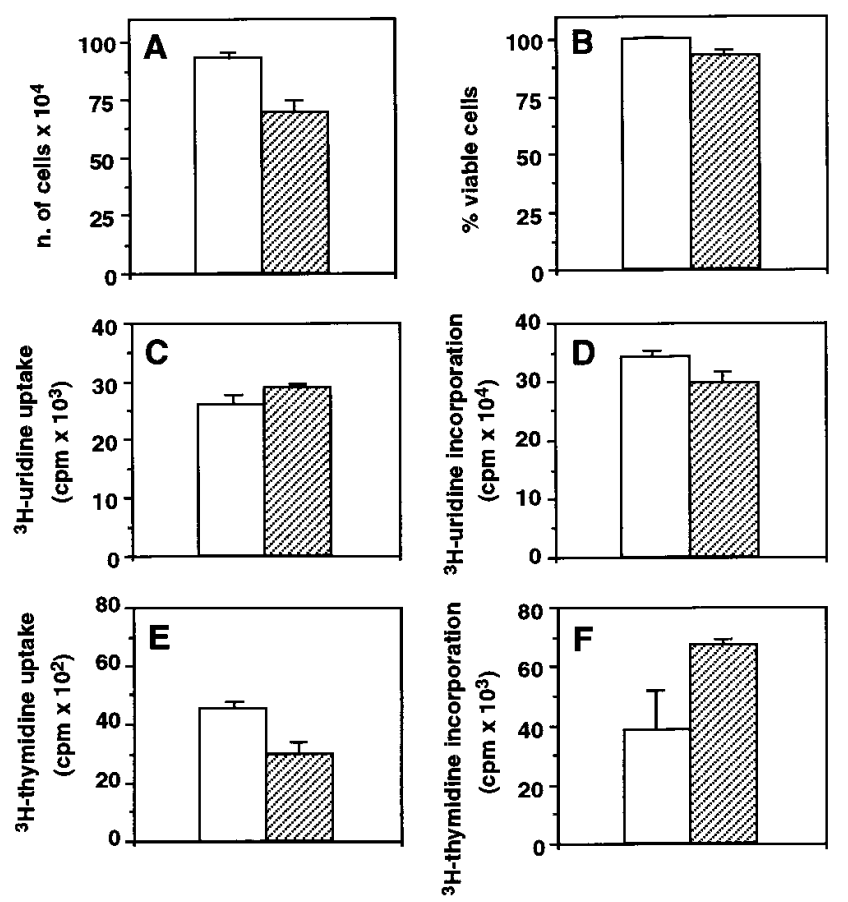

Figure 2. Effect of $\mathrm{PGA}_{1}$ on the proliferation and nucleic acid synthesis in uninfected CEM-SS cells. A, B. CEM-SS cells $\left(5 \times 10^{5}\right.$ cells/ $\mathrm{ml})$ were treated with $\mathrm{PGA}_{1}(4 \mu \mathrm{g} / \mathrm{ml}$, hatched bar $)$ or control diluent (open bar). Numbers of cells $(A)$ and percent viability $(B)$ were determined after $48 \mathrm{~h}$. C-F. CEM-SS cells $\left(1 \times 10^{6} \mathrm{cells} / \mathrm{ml}\right)$ treated with $\mathrm{PGA}_{1}(4 \mu \mathrm{g} / \mathrm{ml}$, hatched bar) or control diluent (open bar) were labeled with $\left[{ }^{3} \mathrm{H}\right]$ uridine $(C$ and $D)$ or $\left[{ }^{3} \mathrm{H}\right]$ thymidine $(E$ and $F$ ), and the amount of radioactivity incorporated into the TCA-soluble (uptake; $C$ and $E$ ) or -insoluble (incorporation; $D$ and $F$ ) material was determined after $24 \mathrm{~h}$. Data represent the mean $\pm \mathrm{SD}$ of duplicate samples $(P>0.05)$. 
the $1 \mathrm{~h}$ adsorption period, the viral inoculum was removed and cells were treated with $\mathrm{PGA}_{1}(4 \mu \mathrm{g} / \mathrm{ml})$ or control diluent. P24 antigen accumulation and the titer of infectious virus were determined in the supernatant of infected cells $96 \mathrm{~h}$ p.i.. Both p24 accumulation and infectious virus production increased in relation to the infectious dose (Fig. 3, $A$ and $B$ ). PGA $_{1}$ was found to dramatically inhibit HIV-1 replication, independently of the infectious dose.

$P G A_{1}$ does not affect an early event in HIV-1 replication cycle. To determine whether $\mathrm{PGA}_{1}$ was acting on an early or a late event during HIV-1 replication cycle, CEM-SS cells were infected with HIV-1 (1 TCID 50 cell) and treated with $4 \mu \mathrm{g} / \mathrm{ml}$ $\mathrm{PGA}_{1}$ soon after the $1 \mathrm{~h}$ adsorption period or at different times p.i. P24 antigen production was determined 96 h p.i. Fig. $4 A$ shows that treatment with $\mathrm{PGA}_{1}$ started as late as $24 \mathrm{~h}$ p.i., was still effective in inhibiting p24 antigen production by more than $90 \%$ of control, indicating that $\mathrm{PGA}_{1}$ did not affect an early event in the virus cycle. In fact, $\mathrm{PGA}_{1}$ was able to moderately $(\sim 50 \%)$ inhibit p24 antigen production, even when treatment was started as late as $48 \mathrm{~h}$ p.i. Addition of $\mathrm{PGA}_{1}(4$ $\mu \mathrm{g} / \mathrm{ml}$ ) to CEM-SS cells only during the virus adsorption period $(1 \mathrm{~h})$ did not inhibit HIV-1 replication (p24 antigen at $96 \mathrm{~h}$ p.i.: control $\left.=174.0 \pm 9.6 \mathrm{ng} / \mathrm{ml} ; \mathrm{PGA}_{1}=202.0 \pm 9.8 \mathrm{ng} / \mathrm{ml}\right)$, indicating that $\mathrm{PGA}_{1}$ does not affect virus adsorption to the cells. Moreover, $\mathrm{PGA}_{1}$, even at much higher concentrations $(50 \mu \mathrm{g} / \mathrm{ml})$, did not alter HIV-1 reverse transcriptase (RT) activity when added directly to the reaction mixture during a RT in vitro assay (Fig. $4 \mathrm{~B}$ ).

The effect of $\mathrm{PGA}_{1}$ treatment on viral DNA accumulation was also investigated. CEM-SS cells were infected with HIV-1 $\left(10 \mathrm{TCID}_{50} / \mathrm{cell}\right)$ and treated with $\mathrm{PGA}_{1}(4 \mu \mathrm{g} / \mathrm{ml})$ or control diluent, soon after the $1 \mathrm{~h}$ adsorption period. At $24 \mathrm{~h}$ p.i., the accumulation of HIV-1 DNA was analyzed by Southern hybridization, using the full length HIV-1 probe, pUCF12-HIV-1 (20), after digestion with EcoRI and BamHI, as described in Methods. As shown in Fig. 5, digestion of DNA from HIV-1infected cells by EcoRI and BamHI resulted in the detection of 2 fragments of 2.7 and $1.1 \mathrm{~kb}$, which represent internal HIV-1 fragments between the EcoRI and the BamHI digestion sites. Higher molecular weight fragments (between 4.5 and $9 \mathrm{~kb}$ ) correspond to digestion within the provirus and the flanking sequences of the human DNA. The results indicate that treatment with $\mathrm{PGA}_{1}$ had no effect on viral DNA accumulation in HIV-1 infected cells (Fig. 5). The effect of PGA treatment on HIV-1 yield was evaluated in the same experiment $96 \mathrm{~h}$ p.i., by determining p24 antigen production $(\mathrm{C}=$ $\left.192.0 \pm 1.1 \mathrm{ng} / \mathrm{ml} ; \mathrm{PGA}_{1}=34.0 \pm 2.7 \mathrm{ng} / \mathrm{ml}\right)$.

$P G A_{1}$ inhibits HIV-1 RNA transcription. To investigate the effect of $\mathrm{PGA}_{1}$ on virus transcription, CEM-SS cells were infected with HIV-1 (1 TCID 50 cell) and treated with PGA $_{1}$ (4 $\mu \mathrm{g} / \mathrm{ml}$ ) or control diluent, soon after the $1 \mathrm{~h}$ adsorption period. Uninfected cells were treated identically. At $48 \mathrm{~h}$ p.i. total RNA was extracted from uninfected and HIV-1 infected cells and analyzed by Northern blot hybridization using a ${ }^{32} \mathrm{P}$-labeled full-length HIV-1 probe or a GAPDH probe as a control. At this time p.i. three major bands of HIV-RNAs could be detected in untreated infected cells corresponding to the nonspliced RNAs (9 kb), the envelope transcripts $(4.2 \mathrm{~kb})$ and the doubly-spliced, nonstructural mRNAs (2 kb), respectively (25). As expected, the accumulation of the 9-kb band, representing the viral genomic RNA and the mRNA for the gag and pol genes, was not as abundant as the two other bands, coding for viral proteins. None of the HIV-1 RNA bands could be observed in $\mathrm{PGA}_{1}$-treated cells, indicating that the expression of HIV-1 provirus is dramatically inhibited in the presence of PGA $_{1}$ (Fig. 6).

Effect of multiple PGA treatments on HIV-1 RNA transcription. To determine the effect of single or multiple $\mathrm{PGA}_{1}$ treatments on HIV-1 RNA transcription in long-term experiments, CEM-SS cells were infected with HIV-1 (1 TCID 50 cell) and treated with $\mathrm{PGA}_{1}$ or control diluent soon after the $1 \mathrm{~h}$ adsorption period. In some samples treatment with $\mathrm{PGA}_{1}$ was repeated on day 3 and 6 p.i. Total RNA was extracted on day 2, 3,5 and 7 after infection, and processed for Northern blot analysis (5 $\mu \mathrm{g} / \mathrm{sample})$, as described above. As shown in Fig. 7, also under these conditions, a single $\mathrm{PGA}_{1}$-treatment completely suppressed HIV-1 RNA expression up to $48 \mathrm{~h}$ p.i. and greatly reduced it even at $72 \mathrm{~h}$ p.i. At 5 and $7 \mathrm{~d}$ p.i. there was no difference in the level of HIV-1 RNA accumulation between control cells and cells which received a single $\mathrm{PGA}_{1}$-treatment, indicating that the block of viral RNA transcription by $\mathrm{PGA}_{1}$ is reversible, and is not due to a generalized toxic effect of $\mathrm{PGA}_{1}$. However, re-addition of $\mathrm{PGA}_{1}$ to infected cells at day 3 and 6 p.i., resulted in a complete block of HIV-1 RNA transcription even at $5 \mathrm{~d}$ after infection, and HIV-1 RNA levels were still reduced at $7 \mathrm{~d}$ p.i., as compared to control. These results, together with the finding that treatment with $\mathrm{PGA}_{1}$ started as late as $24 \mathrm{~h}$ p.i. was effective in reducing HIV-1 mRNA levels
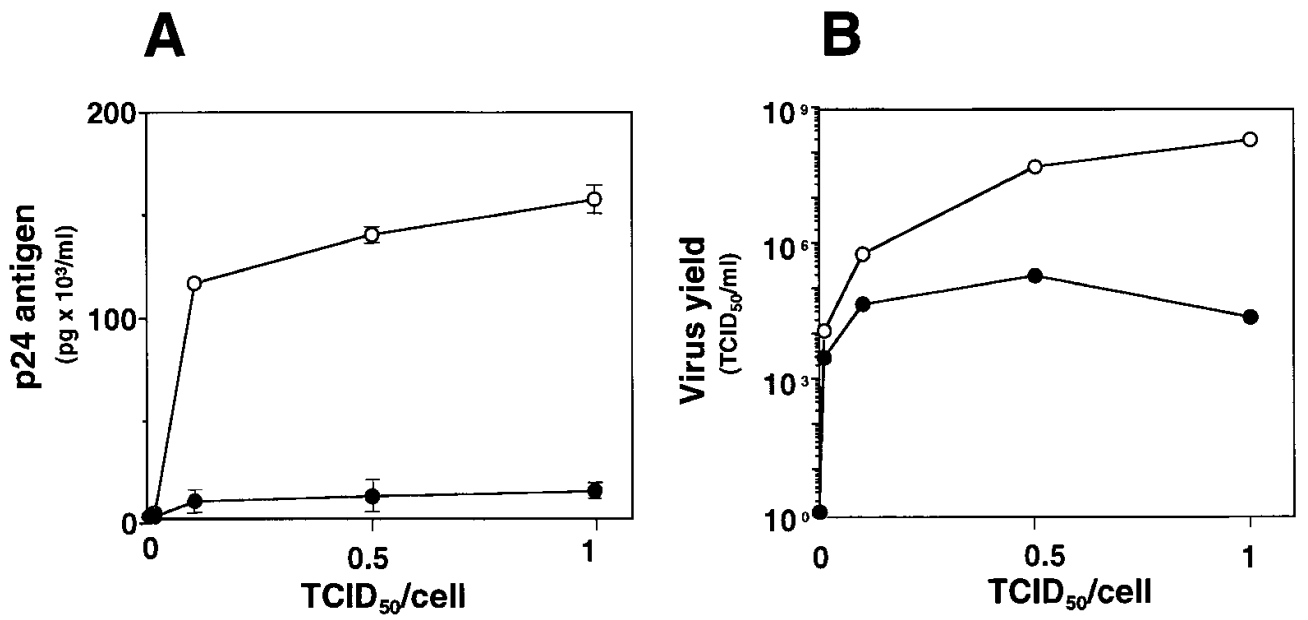

Figure 3. The antiviral effect of $\mathrm{PGA}_{1}$ is independent of the infectious dose. CEM-SS cells were infected with HIV-1 at $0.01,0.1,0.5$, and $1 \mathrm{TCID}_{50} /$ cell and treated with $\mathrm{PGA}_{1}(4 \mu \mathrm{g} / \mathrm{ml}$; -) or control diluent $(\bigcirc)$ soon after the $1 \mathrm{~h}$ adsorption period. p24 antigen production $(A)$ and virus yield $(B)$ were determined 96 h p.i. 
A

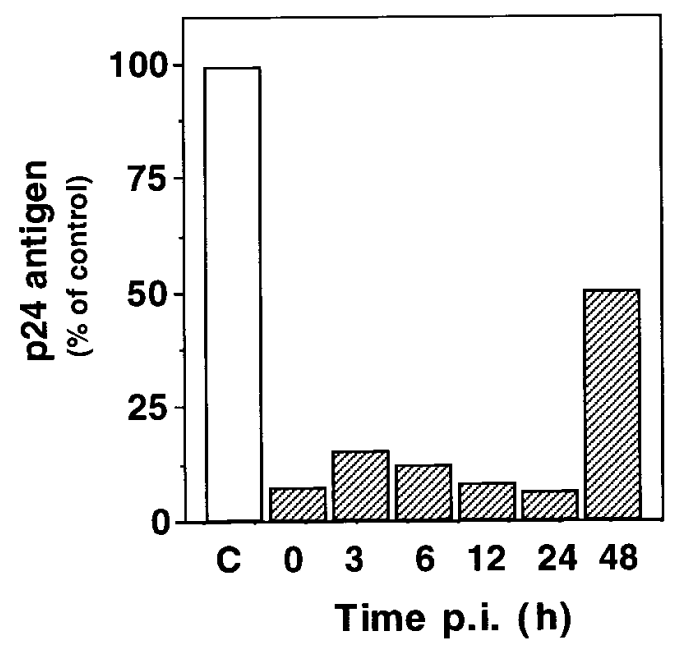

B

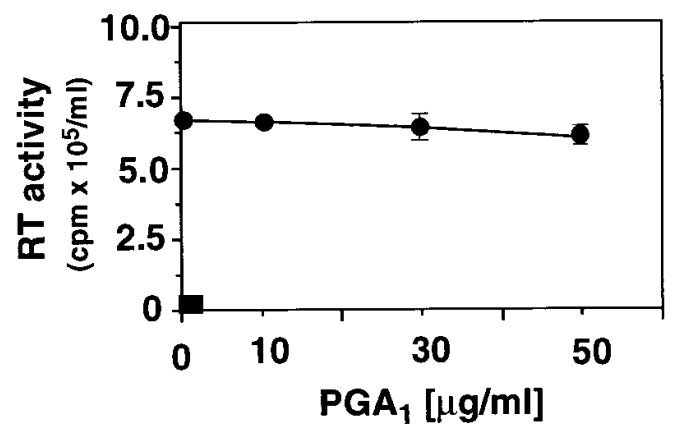

Figure 4. $\mathrm{PGA}_{1}$ does not inhibit an early event in HIV-1 replication cycle. (A) CEM-SS cells were infected with HIV-1 and treated with control diluent (open bar) or $\mathrm{PGA}_{1}(4 \mu \mathrm{g} / \mathrm{ml}$; hatched bar) soon after the $1 \mathrm{~h}$ adsorption period (time 0 ) or at $3,6,12,24$, and $48 \mathrm{~h}$ p.i. P24 antigen production was determined $96 \mathrm{~h}$ p.i. Results are expressed as percent of p24 antigen production in untreated control (control = $165.0 \pm 9.5 \mathrm{ng} / \mathrm{ml})\left(\mathrm{SD}<10 \%\right.$ are not shown). (B) Effect of $\mathrm{PGA}_{1}($ on HIV-1 reverse transcriptase activity in vitro. (ם) Control (no HIV -1 added). Data represent the mean \pm SD of triplicate samples.

for the following $48 \mathrm{~h}$ (data not shown), suggest that HIV-1 RNA transcription could be inhibited by $\mathrm{PGA}_{1}$ treatment even in established infections.

Effect of PGA treatment on HIV-1 protein synthesis. Prostaglandins of the A type have been shown to dramatically reduce the synthesis of virus proteins during acute infection with different negative-strand RNA viruses $(26,27)$. To investigate the effect of PGA $_{1}$-treatment on HIV-1 protein synthesis, CEM-SS cells were infected with HIV-1 (1 TCID 50 cell) and treated with $\mathrm{PGA}_{1}(4 \mu \mathrm{g} / \mathrm{ml})$ or control diluent soon after the $1 \mathrm{~h}$ adsorption period. Treatment was not repeated in the following $96 \mathrm{~h}$. At different times, the intracellular levels of viral proteins were analyzed by immunoblot analysis with antiHIV-1 or anti-p24 gag antibodies. As shown in Fig. 8, the levels of intracellular p24 antigen were dramatically reduced up to $96 \mathrm{~h}$ p.i., as determined by ELISA or by Western blot analysis. At this time after infection, $\mathrm{PGA}_{1}$ only moderately inhib-

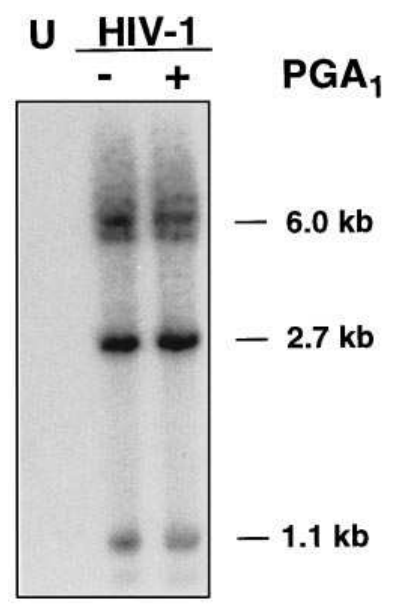

Figure 5. Effect of $\mathrm{PGA}_{1}$ on HIV-1 DNA accumulation. CEM-SS cells were infected with HIV-1 (10 $\mathrm{TCID}_{50} /$ cell $)$ and treated with $\mathrm{PGA}_{1}(+)$ or control diluent (-) soon after the $1 \mathrm{~h}$ adsorption period. Uninfected cells $(\mathrm{U})$ received the same amount of control diluent. At $24 \mathrm{~h}$ p.i. cells were harvested $\left(10^{7}\right.$ cells/sample $)$ and genomic DNA was isolated, restricted with EcoRI and BamHI, and analyzed by Southern hybridization using ${ }^{32} \mathrm{P}$-labeled pUCF12-HIV-1 plasmid, as described in Methods. The 2.7- and 1.1-kb fragments represent the internal HIV-1 fragments between the EcoRI and BamHI

digestion sites. Higher molecular weight fragments correspond to digestion within the provirus and the flanking sequences of the human DNA.

ited total protein synthesis in HIV-1-infected cells, as determined by $\left[{ }^{35} \mathrm{~S}\right]$ methionine incorporation $\left(5 \mu \mathrm{Ci} / 10^{6}\right.$ cells, $6 \mathrm{~h}$ pulse). The synthesis of all HIV-1 virus proteins was inhibited by a single $\mathrm{PGA}_{1}$ treatment up to $96 \mathrm{~h}$ p.i., as determined by immunoblot analysis using polyclonal anti-HIV-1 antibodies, followed by ECL (data not shown).

$P G A_{1}$ does not induce the expression of cytokines in HIV-1 infected cells. It has been reported that specific cytokines may modulate HIV-1 infection in cells of both the monocyte/macrophage and the lymphocyte lineage (28). To determine whether $\mathrm{PGA}_{1}$ treatment could modulate cytokine expression during HIV-1 replication cycle, infected CEM-SS cells were treated with $4 \mu \mathrm{g} / \mathrm{ml}$ or control diluent, soon after the $1 \mathrm{~h}$ adsorption period. At different time intervals, total RNA was extracted from $\mathrm{PGA}_{1}$-treated or untreated cultures, and analyzed by Northern blot, using ${ }^{32} \mathrm{P}$-labeled specific oligonucleotides for IL-6, IL-10, TNF- $\alpha$, TNF- $\beta, \alpha$-IFN, $\beta$-IFN, and $\gamma$-IFN. Under the conditions examined, high levels of TNF- $\beta$ mRNA were found to accumulate in HIV-1 infected CEM-SS cells up to $96 \mathrm{~h}$ p.i., while low levels of TNF- $\alpha, \gamma$-IFN, IL-10, and IL-6 were

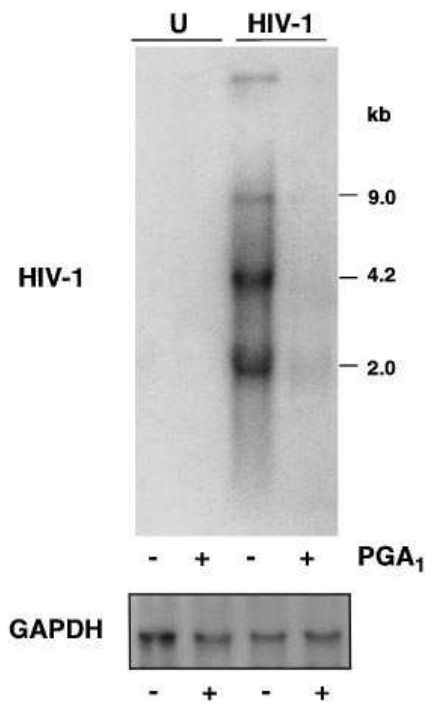

Figure 6. Inhibition of HIV-1 RNA expression by $\mathrm{PGA}_{1}$. Uninfected (U) or HIVinfected (HIV-1) CEM-SS cells were treated with $4 \mu \mathrm{g} / \mathrm{ml}$ $\mathrm{PGA}_{1}(+)$ or control diluent $(-)$ soon after the $1 \mathrm{~h}$ adsorption period. At $48 \mathrm{~h}$ p.i. total RNA was extracted and analyzed by Northern blotting using the ${ }^{32} \mathrm{P}$-labeled pUCF12HIV-1 probe. Levels of GAPDH mRNA in the same samples are shown as control. 


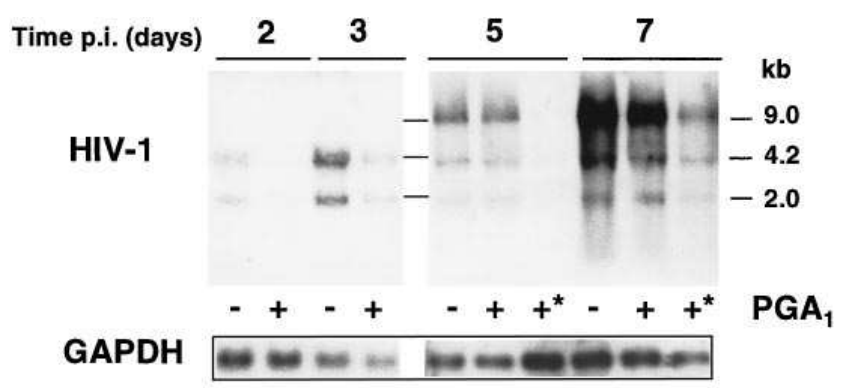

Figure 7. Long-term inhibition of HIV-1 RNA expression by multiple PGA $_{1}$-treatments. CEM-SS cells were infected with HIV-1 and treated with $4 \mu \mathrm{g} / \mathrm{ml} \mathrm{PGA}_{1}(+)$ or control diluent (-) soon after the $1 \mathrm{~h}$ adsorption period. (+*) $\mathrm{PGA}_{1}$-treatment $(4 \mu \mathrm{g} / \mathrm{ml})$ was repeated every 3 d. At days $2,3,5$, and 7 p.i., total RNA was extracted and analyzed by Northern blotting using the ${ }^{32} \mathrm{P}$-labeled pUCF12-HIV-1 probe. Levels of GAPDH mRNA in the same samples are shown as control.

detected. No accumulation of $\alpha$-IFN and $\beta$-IFN mRNAs was observed. No difference in the levels of accumulation of any of the cytokines examined were found between $\mathrm{PGA}_{1}$-treated and untreated cells, up to $96 \mathrm{~h}$ p.i. (data not shown).

Effect of $\mathrm{PGJ}_{2}$ on HIV-1 replication in CEM-SS cells. Prostaglandins of the $\mathrm{J}$ type have been shown to potently suppress the replication of several RNA viruses $(10,26,27,29)$. To investigate the effect of $\mathrm{PGJ}_{2}$ on $\mathrm{HIV}-1$ replication, CEM-SS cells were infected with HIV-1 ( $1 \mathrm{TCID}_{50} /$ cell) and treated with different concentrations of $\mathrm{PGJ}_{2}$ or control diluent soon after the $1 \mathrm{~h}$ adsorption period. Virus production from untreated and $\mathrm{PGJ}_{2}$-treated infected cells was determined $4 \mathrm{~d}$ p.i., measuring p24 extracellular levels by ELISA. As shown in Fig. $9 \mathrm{~A}, \mathrm{PGJ}_{2}$ treatment caused a dose-dependent decrease in p24 antigen production; doses as low as $1.5-2 \mu \mathrm{g} / \mathrm{ml}$ inhibited p24 antigen production by $>90 \%$ as compared with control, while higher concentrations almost completely abolished p24 antigen production. To investigate whether $\mathrm{PGJ}_{2}$ treatment was

A
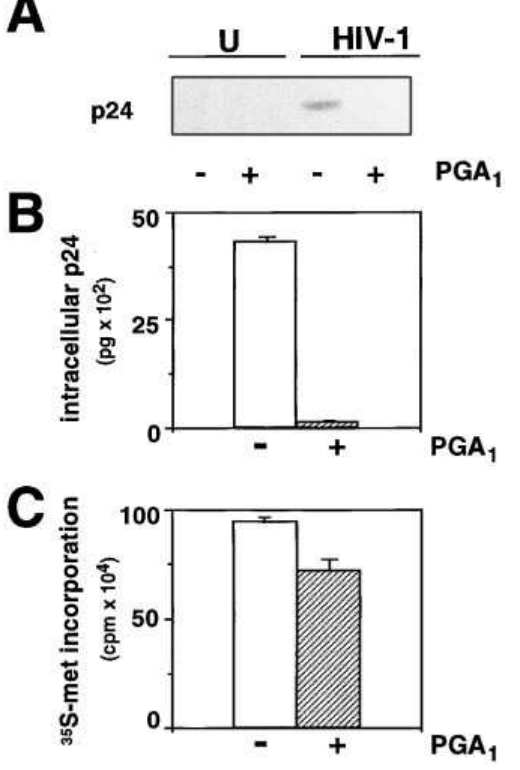

Figure 8. Effect of $\mathrm{PGA}_{1}$-treatment on HIV-1 p24 antigen synthesis. Uninfected (U) or HIV-1-infected (HIV-1) CEM-SS cells were treated with $4 \mu \mathrm{g} /$ $\mathrm{ml} \mathrm{PGA}_{1}(+)$ or control diluent $(-)$ soon after the $1 \mathrm{~h}$ adsorption period. Treatment was not repeated. After $96 \mathrm{~h}$ cells were labeled with $\left.{ }^{35} \mathrm{~S}\right]$ methionine $(6 \mathrm{~h}$ pulse), and levels of intracellular p24 antigen were determined by immunoblot analysis $(A)$ or by ELISA $(B)$. Total protein synthesis was determined as $\left[{ }^{35} \mathrm{~S}\right] \mathrm{me}-$ thionine incorporation into TCA-insoluble material $(C)$.
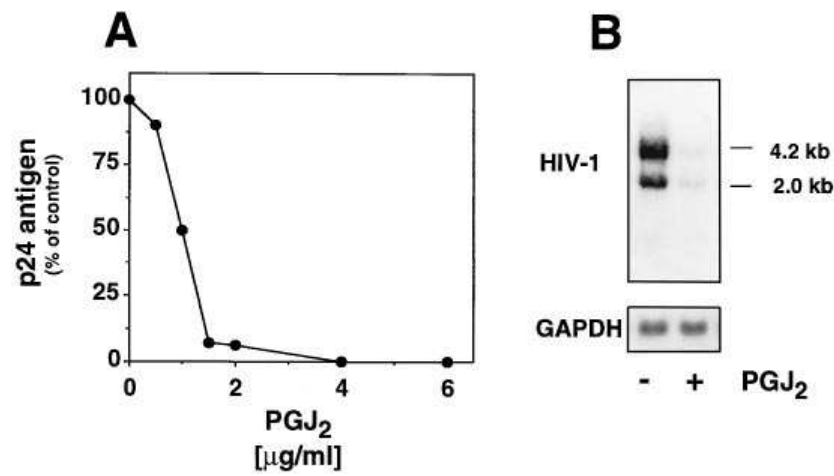

Figure 9. Inhibition of HIV-1 replication by $\mathrm{PGJ}_{2}$. (A) CEM-SS cells infected with HIV-1 were treated with different concentrations of $\mathrm{PGJ}_{2}$ or control diluent soon after the $1 \mathrm{~h}$ adsorption period. P2 4 antigen production was determined $96 \mathrm{~h}$ p.i. by ELISA. Results are expressed as percent of $\mathrm{p} 24$ antigen production in untreated control (control: $152.0 \pm 10.1 \mathrm{ng} / \mathrm{ml}$ ). SD $<10 \%$ are not shown. (B) Hybridization analysis of HIV-specific RNA at $48 \mathrm{~h}$ after infection with HIV-1 in CEM-SS cells treated with $2 \mu \mathrm{g} / \mathrm{ml} \mathrm{PGJ}_{2}(+)$ or control diluent $(-)$. Levels of GAPDH mRNA in the same samples are shown as control.

also effective in inhibiting HIV-1 RNA transcription, CEM-SS cells were infected with HIV-1 and treated with PGJ $_{2}(2 \mu \mathrm{g} /$ $\mathrm{ml}$ ) or control diluent, as described above. Total RNA was extracted from untreated or $\mathrm{PGJ}_{2}$-treated HIV-1 infected cells at $48 \mathrm{~h}$ p.i., and processed for Northern blot analysis. As described above for $\mathrm{PGA}_{1}, \mathrm{PGJ}_{2}$ treatment was found to dramatically inhibit HIV-1 mRNA expression in CEM-SS cells (Fig. 9 B).

Finally, the antiviral activity of $\mathrm{PGA}_{1}$ and $\mathrm{PGJ}_{2}$ was compared with the effect of AZT-treatment in the same cells. CEM-SS cells were infected with HIV-1 (1 TCID To cell) and treated with AZT $(5 \mu \mathrm{M}), \mathrm{PGA}_{1}(2.5,5$ or $10 \mu \mathrm{M})$ or control diluent, soon after the $1 \mathrm{~h}$ adsorption period. In a separate experiment, CEM-SS cells were infected with HIV-1 (1 TCID Tol cell) and treated with $5 \mu \mathrm{M}$ AZT, $4 \mu \mathrm{M} \mathrm{PGJ}_{2}$, or control diluent, as described above. After $96 \mathrm{~h}$ cell supernatants were collected and analyzed for p24 antigen accumulation. As shown in Fig. 10, the antiviral activity of $\mathrm{PGA}_{1}$ and $\mathrm{PGJ}_{2}$ was comparable with that of AZT treatment in these cells.

\section{Discussion}

Prostaglandins are a class of naturally occurring cyclic 20-carbon fatty acids with potent biological properties. In eukaryotic cells, they are synthesized from arachidonic acid and other polyunsaturated fatty acid precursors derived from the phospholipid pool of the cell membrane in response to external stimuli, such as cell injury and inflammation (30) and function as intracellular signal mediators in the regulation of physiological and pathological processes, including inflammation and the febrile response $(31,32)$, cytoprotection (33), cell proliferation and differentiation (34) and virus replication $(3,15)$.

The antiviral activity of natural and synthetic arachidonic acid-derived cyclopentenones has been described in several DNA and RNA virus models in vitro and in vivo, at concentrations which are nontoxic to the host cell. Compared with other chemotherapeutic agents, the antiviral activity of cyclopentenone PGs is characterized by a wide spectrum of action, since it affects both naked or enveloped DNA and RNA viruses, 


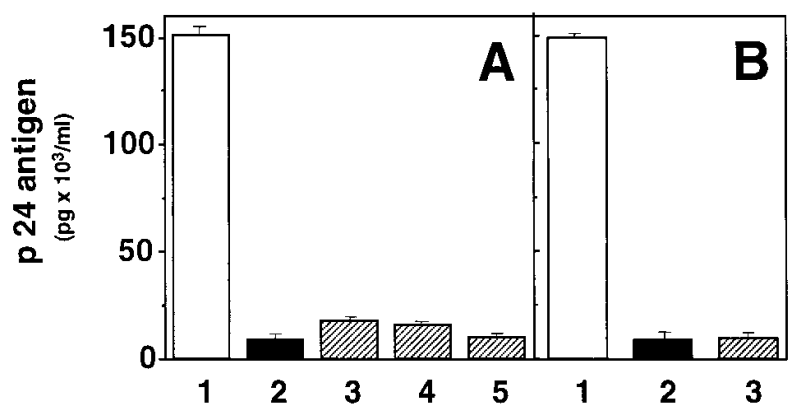

Figure 10. Inhibition of HIV-1 replication by cyclopentenone prostaglandins is comparable to AZT treatment. $(A)$ CEM-SS cells were infected with HIV-1 (1 TCID 50 cell) and treated with $5 \mu \mathrm{M} \mathrm{AZT} \mathrm{(bar}$ 2), 2.5, 5 or $10 \mu \mathrm{M} \mathrm{PGA}_{1}$ (bars 3, 4, and 5, respectively) or control diluent (bar 1), soon after the $1 \mathrm{~h}$ adsorption period. $(B)$ In a separate experiment, CEM-SS cells were infected with HIV-1 (1 TCID To $_{0} /$ cell $)$ and treated with $5 \mu \mathrm{M}$ AZT (bar 2), $4 \mu \mathrm{M} \mathrm{PGJ}_{2}$ (bar 3), or control diluent (bar 1) as described above. P24 antigen production was determined 96 h p.i. by ELISA.

and by the ability to suppress virus replication even when administered in relatively late stages of the virus replication cycle (reviewed in references 15 and 24). These characteristics make cyclopentenone PGs an interesting new class of antiviral agents which could be readily available, since they can be synthesized chemically and since a large variety of prostanoids analogous to PGA can be obtained from natural sources, especially marine organisms (35).

The mechanism of the antiviral activity is not completely elucidated. Cyclopentenone PGs appear to act at more than one level during the virus replication cycle. In several virus models, the target for the antiviral activity is a late event in the virus replication cycle, and PGs cause alterations in the synthesis, glycosylation and intracellular translocation of viral proteins $(6,11,36)$, resulting in a block of virus maturation and budding from infected cells. On the other hand, a PGA -medi- $^{-}$ ated block of virus RNA synthesis in an early stage of virus infection was shown in human cells infected with herpesvirus type 1 (5) and in murine cells infected with vesicular stomatitis virus (VSV) (12). Moreover, it has been shown that cyclopentenone PGs can affect more than one event during the viral replication cycle in the same virus-host cell model. In fact, treatment with $\mathrm{PGA}_{1}$ and $\mathrm{PGJ}_{2}$ in a late phase of infection by the rhabdovirus VSV or the paramyxovirus Sendai (SV), causes a dramatic block of infectious virus production, which is mediated by alterations in the maturation and intracellular translocation of the VSV glycoprotein G, or the SV glycoproteins hemoagglutinin neuraminidase $(\mathrm{HN})$ and fusion $(\mathrm{F})$, respectively $(11,27,36)$. Treatment with the drugs soon after infection results, instead, in a selective and dramatic inhibition of virus protein synthesis and in the protection of the host cell from the virus-induced shut-off of cellular protein synthesis $(26,27)$. This block has been shown to be exerted at the translational level, and is dependent upon the induction of a $70-\mathrm{kD}$ heat shock protein (hsp70) in infected cells $(15,26)$.

Prostaglandins with antiviral activity, in fact, function as a signal for the induction of heat shock proteins (HSP) and in particular of hsp70 in a large variety of mammalian and human cells lines, as well as in human peripheral blood lymphocytes, macrophages and primary cells derived from cord blood (24,
37). Induction of hsp70 gene transcription by prostaglandin A is mediated by cycloheximide-sensitive activation of heat shock transcription factor (HSF), which binds to the heat shock element composed of multiple adjacent inverted repeats of the pentamer nGAAn (38), and it has been recently associated with the antiviral activity of these molecules (reviewed in reference 15).

In the present study, we have demonstrated that two cyclopentenone prostaglandins, $\mathrm{PGA}_{1}$ and $\mathrm{PGJ}_{2}$, are extremely effective in suppressing HIV-1 replication during acute infection in lymphoblastoid CEM-SS cells. A 10-fold reduction of p24 antigen production, and an over 1000 -fold reduction in infectious virus yield, as determined by infectious virus titration, can be obtained at concentrations of prostaglandins which are not toxic to the cells and do not inhibit nucleic acid synthesis in uninfected CEM-SS cells. The antiviral activity was found to be comparable to that of AZT treatment in these cells.

Prostaglandins did not affect the adsorption and penetration of the virus into the host cell, nor an early event in HIV-1 replication cycle, since $\mathrm{PGA}_{1}$ was found not to alter the accumulation of viral DNA up to $24 \mathrm{~h}$ p.i., and treatment started as late as $24 \mathrm{~h}$ p.i. was still effective in inhibiting virus replication. HIV-1 reverse transcriptase activity was also unaffected by $\mathrm{PGA}_{1}$. Both $\mathrm{PGA}_{1}$ and $\mathrm{PGJ}_{2}$ were found to dramatically suppress HIV-1 mRNA expression in these cells up to $48-72 \mathrm{~h}$ p.i. Synthesis of HIV-1 proteins was consequently inhibited up to $96 \mathrm{~h}$ after infection. Delayed (up to $24 \mathrm{~h}$ p.i.) and repeated $\mathrm{PGA}_{1}$-treatments were effective in protecting CEM-SS cells by the cytopathic effect of the virus, and in reducing HIV-1 RNA levels up to $7 \mathrm{~d}$ after infection, suggesting that HIV-1 RNA transcription could be inhibited also in established infections.

The inhibition of HIV-mRNA expression does not appear to be mediated by different cytokines, including $\alpha, \beta$, or $\gamma$-interferon, TNF- $\alpha$, TNF- $\beta$, IL6, or IL10, whose expression is not altered by $\mathrm{PGA}_{1}$ in HIV-1-infected CEM-SS cells. Cyclopentenone prostaglandins may be affecting other intracellular signalling pathways used by HIV-1 to regulate its expression, including activation of the transcription factor NF-кB (39), or the synthesis of heat shock proteins and cyclophilins, whose role in the control of HIV-1 life cycle has been recently described (reviewed in reference 40 ). $\mathrm{PGA}_{1}$ has in fact been shown to induce the expression of an oxidative stress-regulated protein, heme oxygenase (41), as well as other heat shock proteins $(15,24,37)$. As described above, hsp70 has been shown to participate in the $\mathrm{PGA}_{1}$-induced block of virus protein translation in cells infected with negative-strand RNA viruses (26). Since $\mathrm{PGA}_{1}$ is able to induce the synthesis of elevated intracellular levels of hsp70 in HIV-1-infected CEM-SS cells up to $24 \mathrm{~h}$ after treatment (De Marco et al., manuscript in preparation), it could be hypothesized that, also in the case of retrovirus infection, hsp70 could interfere with virus mRNA transcription directly, or by inhibiting the translation of the trans-acting regulatory HIV-1 proteins Tat or Rev, which would in turn result in a block of HIV-1 gene expression (42).

Based on the results obtained in other virus models, we cannot exclude that $\mathrm{PGA}_{1}$ is acting at more than one level during HIV-1 replication cycle. In fact, the finding that in the same samples the production of p24 antigen is reduced by $\sim 10$-fold, while the virus yield, as measured by titration of infectious virus, is reduced by over 1000 -fold by $\mathrm{PGA}_{1}$-treatment, indicates that not only $\mathrm{PGA}_{1}$ inhibits $\mathrm{HIV}-1$ production 
by infected cells, but that a large amount of the virus particles produced are not infectious. This suggests that HIV-1 glycoprotein maturation and intracellular translocation could also be affected by $\mathrm{PGA}_{1}$, as previously shown for VSV G glycoprotein (11), and Sendai virus HN and F glycoproteins (36), and deserves further investigation.

It should be pointed out that concentrations of $\mathrm{PGA}_{1}$ higher than $1 \mu \mathrm{M}$ were necessary to inhibit HIV-1 replication in our in vitro model, indicating a pharmacological effect. Whether the level of cyclopentenone prostaglandins could achieve a sufficiently high local concentration to inhibit HIV-1 replication in vivo during pathological conditions that cause an increase in arachidonic acid metabolism, such as hyperthermia (43), remains to be established.

Prostaglandins are used clinically in the treatment of congenital heart disease and gastric ulcers, and to facilitate labor, and are generally effective and well tolerated. In studies on volunteers with hypertension, infusion with $\mathrm{PGA}_{1}$ was reported to have a beneficial effect on the patients' blood pressure $(44,45)$, while no deleterious effects on kidney function nor other significant side-effects were found. These observations, together with the progress in the understanding of the mechanism of antiviral action, encourage the search for new prostanoids with antiretroviral activity and make cyclopentenone prostaglandins a new class of potential therapeutic agents for HIV-1 infection.

\section{Acknowledgments}

We thank M. Federico for the pUCF12-HIV-1 plasmid.

This work was supported by a grant from the Italian Ministry of Public Health, VIII AIDS Research project (1995). A. Carattoli and A. De Marco were supported by a Fellowship for AIDS Research from the Italian Ministry of Public Health.

\section{References}

1. Yarchoan, R., H. Mitsuya, and S. Broder. 1993. Challenges in the therapy of HIV infection. Immunol. Today. 14:303-309.

2. St. Clair, M.H., J.L. Martin, G. Tudor-Williams, M.C. Bach, C.L. Vavro, D.M. King, P. Kellam, S.D. Kemp, and B.A. Larder. 1991. Resistance to ddI and sensitivity to AZT induced by a mutation in HIV-1 reverse transcriptase. Science (Wash. DC). 1253:1557-1559.

3. Santoro, M.G., A. Benedetto, G. Carruba, E. Garaci, and B.M. Jaffe. 1980. Prostaglandin A compounds as antiviral agents. Science (Wash. DC). 209: 1032-1034.

4. Hughes-Fulford, M., M.S. McGrath, D. Hanks, S. Erickson, and L. Pulliam. 1992. Effects of dimethyl prostaglandin $\mathrm{A}_{1}$ on Herpes Simplex Virus and Immunodeficiency Virus replication. Antimicrob. Agents Chemother. 36:22532258.

5. Yamamoto, N., M. Fukushima, T. Tsurumi, K. Maeno, and Y. Nishiyama. 1987. Mechanism of inhibition of herpes simplex virus replication by $\Delta^{7}$-prostaglandin $\mathrm{A}_{1}$ and $\Delta^{12}$-prostaglandin $\mathrm{J}_{2}$. Biochem. Biophys. Res. Commun. 146: $1425-1431$.

6. Santoro, M.G., B.M. Jaffe, E. Garaci, and M. Esteban. 1982. Antiviral effect of prostaglandins of the A series: inhibition of vaccinia virus replication in cultured cells. J. Gen. Virol. 63:435-440.

7. Amici, C., and M.G. Santoro. 1991. Suppression of Sendai virus replication by prostaglandin A is associated with heat shock protein synthesis. J. Gen. Virol. 72:1877-1885.

8. Santoro, M.G., C. Favalli, A. Mastino, B.M. Jaffe, M. Esteban, and E. Garaci. 1988. Antiviral activity of a synthetic analog of prostaglandin A in mice infected with influenza A virus. Arch. Virol. 99:89-100.

9. Ankel, H., S. Mittnacht, and H. Jacobsen. 1985. Antiviral activity of prostaglandin A on encephalomyocarditis virus-infected cells: a unique effect unrelated to interferon. J. Gen. Virol. 66:2355-2364.

10. Mastromarino, P., C. Conti, R. Petruzziello, A. De Marco, F. Pica, and M.G. Santoro. 1993. Inhibition of Sindbis virus replication by cyclopentenone prostaglandins: a cell-mediated event associated with heat shock protein synthesis. Antiviral Res. 20:209-222.
11. Santoro, M.G., B.M. Jaffe, and M. Esteban. 1983. Prostaglandin A inhibits the replication of vesicular stomatitis virus: effect on virus glycoprotein. $J$. Gen. Virol. 64:2797-2801.

12. Bader, T., and H. Ankel. 1990. Inhibition of primary transcription of vesicular stomatitis virus by prostaglandin $\mathrm{A}_{1}$. J. Gen. Virol. 71:2823-2832.

13. D'Onofrio, C., E. Alvino, E. Garaci, E. Bonmassar, and M.G. Santoro. 1990. Selection of HTLV-I positive clones is prevented by prostaglandin A in cord blood cultures. Br. J. Cancer. 61:207-214.

14. Ankel, H., O. Turriziani, and G. Antonelli. 1991. Prostaglandin A inhibits replication of human immunodeficiency virus during acute infection. J. Gen. Virol. 72:2797-2800.

15. Santoro, M.G. 1994. Heat shock proteins and virus replication: hsp70 as mediators of the antiviral effects of prostaglandins. Experientia. 50:1039-1047.

16. Rey, M.A., B. Krust, A.G. Laurent, L. Montagnier, and A.G. Hovanessian. 1989. Characterization of human immunodeficiency virus type 2 envelope glycoproteins: dimerization of the glycoprotein precursor during processing. $J$. Virol. 63:647-658.

17. Popovic, M., M.G. Sarngadharan, E. Read, and R.C. Gallo. 1984. Detection, isolation and continuous production of cytopathic retroviruses (HTLVIII) from patients with AIDS and pre-AIDS. Science (Wash. DC). 224:497-500.

18. Johnson, V.A., and R.E. Byington. 1990. Quantitative assay for virus infectivity. In Techniques in HIV Research. Aldovini, A., and D.B. Walker, editors. Stockton Press, New York, London, Tokyo. 71-76.

19. Chomczynski, P., and N. Sacchi. 1987. Single step method of RNA isolation by acid guanidinium thiocyanate-phenol-chloroform extraction. Anal. Biochem. 162:156-159.

20. Carlini, F., Federico, M., Equestre, M., Ricci, S., Ratti, G., Zibai, Q.I., Verani, P., and G.B. Rossi. 1992. Sequence analysis of an HIV-1 proviral DNA from a non-producer chronically infected HUT78 cellular clone. J. Viral Disease. 1:40-55.

21. Enrietto, P.J., Payne, L.N., and M.J. Hayman. 1983. A recovered avian myelocytomatosis virus that induces lymphomas in chickens: pathogenic properties and their molecular basis. Cell. 35:367-379.

22. Shirazi, Y., and P.M. Pitha. 1992. Alpha interferon inhibits early stages of the human immunodeficiency virus type 1 replication cycle. J. Virol. 66:13211328.

23. Rossi, G.B., P. Verani, B. Macchi, M. Federico, A. Orecchia, L. Nicoletti, S. Buttò, A. Lazzarin, G. Mariani, G. Ippolito, and V. Manzari. 1988. Recovery of HIV-related retrovirus from italian patients with AIDS or AIDS related complex and from asymptomatic at-risk individuals. Ann. NY Acad. Sci. 511:390-400.

24. Santoro, M.G., E. Garaci, and C. Amici. 1991. Induction of heat shock protein synthesis by prostaglandins with antineoplastic and antiviral activity. In Advances in Prostaglandin, Thromboxane, and Leukotriene Research. B. Samuelsson, P.W. Ramwell, R. Paoletti, G. Folco, and E. Granström, editors. Raven Press, New York. Vol: 21 B. 867-874.

25. Kim, S., R. Byrn, J. Groopman and D. Baltimore. 1989. Temporal aspects of DNA and RNA synthesis during human immunodeficiency virus infection: evidence for differential gene expression. J. Virol. 63:3708-3713.

26. Amici, C., C. Giorgi, A. Rossi, and M.G. Santoro. 1994. Selective inhibition of virus protein synthesis by prostaglandin $\mathrm{A}_{1}$ : a translational block associated with HSP70 synthesis. J. Virol. 68:6890-6899.

27. Pica, F., A. De Marco, F. De Cesare and M.G. Santoro. 1993. Inhibition of vesicular stomatitis virus replication by $\Delta^{12}$-prostaglandin $\mathbf{J}_{2}$ is regulated at two separate levels and is associated with induction of stress protein synthesis. Antiviral Res. 20:193-208.

28. Rosenberg, Z.F., and A.S. Fauci. 1990. Immunopathogenic mechanisms of HIV-infection: cytokine induction of HIV expression. Immunol. Today. 11: $176-180$.

29. Fukushima, M. 1990. Prostaglandin $\mathbf{J}_{2}$-anti-tumor and anti-viral activities and the mechanisms involved. Eicosanoids. 3:189-199.

30. Samuelsson, B. 1982. Prostaglandins, thromboxanes and leukotrienes: biochemical pathways. In Prostaglandins and Cancer: First International Conference. T.J. Powles, R.S. Bockman, K.V. Honn, P. Ramwell, editors. Alan R. Liss Inc., New York. 1-19.

31. Vane, J.R. 1987. Antiinflammatory drugs and the arachidonic acid cascade. In Prostaglandins in Cancer Research. E. Garaci, R. Paoletti, and M.G. Santoro, editors. Springer-Verlag, Berlin. 12-28.

32. Dinarello, C.A., and S.M. Wolff. 1982. Molecular basis of fever in humans. Am. J. Med. 72:799-819.

33. Robert, A. 1981. Prostaglandins and the gastrointestinal tract. In Physiology of the Gastrointestinal Tract. L.R. Johnson, editor. Raven Press, New York. 1407-1434.

34. Garaci, E., R. Paoletti, and M.G. Santoro. 1987. Prostaglandins in Cancer Research. Springer-Verlag, Berlin. 242 pp.

35. Ciereszko, L.S., Y. Gopichand, F.J. Schmitz, W.P. Schneider, and G.L. Bundy. 1985. Prostaglandin (15S)-PGA derivatives in the gorgonian Plexaura homomalla (Esper), forma kukenthali Moser. Experientia. 41:37-38.

36. Santoro, M.G., C. Amici, G. Elia, A. Benedetto, and E. Garaci. 1989. Inhibition of virus protein glycosylation as the mechanism of the antiviral action of prostaglandin A in Sendai virus-infected cells. J. Gen. Virol. 70:789-800.

37. Santoro, M.G., E. Garaci, and C. Amici. 1989. Prostaglandins with anti- 
proliferative activity induce the synthesis of a heat shock protein in human cells. Proc. Natl. Acad. Sci. USA. 86:8407-8411.

38. Amici, C., L. Sistonen, M.G. Santoro, and R.I. Morimoto. 1992. Antiproliferative prostaglandins activate heat shock transcription factor. Proc. Natl. Acad. Sci. USA. 89:6227-6231.

39. Cullen, B.R. 1991. Regulation of HIV-1 gene expression. FASEB J. 5: 2361-2368.

40. Santoro, M.G. 1996. Virus infection. In Stress-Inducible Cellular Responses. U. Feige, R.I. Morimoto, I. Yahara, and B.S. Polla, editors. Birkhauser Verlag, Basel-Boston-Berlin. In press.

41. Rossi, A., and M.G. Santoro. 1995. Induction by prostaglandin $\mathrm{A}_{1}$ of heme oxygenase in myoblastic cells: an effect independent of expression of the 70KDa heat shock protein. Biochem. J. 308:455-463.
42. Rosen, C.A. 1991. Regulation of HIV gene expression by RNA-protein interactions. Trends Genet. 7:9-14.

43. Calderwood, S.K., Bornstein, B., Farnum, E.K., and M.A. Stevenson. 1989. Heat shock stimulates the release of arachidonic acid and the synthesis of prostaglandins and leukotriene $\mathrm{B}_{4}$ in mammalian cells. J. Cell. Physiol. 141:325333.

44. Lee, J., H. Kannegiesser, J. O'Toole, and E. Westura. 1971. Hypertension and the renomedullary prostaglandins: a human study of the antihypertensive effects of $\mathrm{PGA}_{1}$. Ann. NY Acad. Sci. 180:218-240.

45. Westura, E.E., H. Kannegiesser, J. O'Toole, and J.B. Lee. 1970. Antihypertensive effects of prostaglandin $\mathrm{A}_{1}$ in essential hypertension. Circulation Res. (Suppl. 1) 18:131-137. 